\title{
Princes and Governors: The Legal-Historical Glossa to the Janusz Bieniak's Conception of a Constitutional Order in the Second Piasts' Monarcby ${ }^{*}$
}

\begin{abstract}
In the paper, an attempt of eliminating a certain supposed internal contradiction in the concept of Janusz Bieniak concerning the role and position of junior members of the Piast dynasty in the territorial governance of the so called second Polish monarchy (ca 1040-1177) was undertaken. As the result of the conducted reasoning, three probable and one hypothetic model of engaging the junior Piasts in the management of provinces were discerned, two of which (1. and 2.) included co-existence in a given province of a Piast duke and a noblemen appointed by the "grand duke" (princeps), and two: officiating of sole members of the dynasty as governors or rulers in the provinces of the monarchy. All those models must be taken into account in further research on the constitutional and political history of the Piast state in the eleventh and twelfth centuries.
\end{abstract}

Keywords: history of government, Piast dynasty, Poland, Middle Ages, territorial governance

Given the wealth of the accumulated research and the lack of any new sources, the constitutional history of the second Piast monarchy is one of the subjects where there is little room for progress. Any attempt to revisit that field - barring a most unlikely revolutionary shake-up - cannot but follow the well-trodden paths and hope, at best, to add a weighty footnote to the work of others. It is no different with this article, which is a gloss, or a note-and-query, added to Janusz Bieniak's well-founded, terse characterization of Poland's political and constitutional system in the $12^{\text {th }}$ century. In his view, it functioned until at least 1177 unaffected by the division of the country into five principalities (enacted in 1138), because Bolesław the Wrymouth's (Bolesław Krzywousty)

* Polish text: Książęta i namiestnicy. Historycznoustrojowa glossa do Janusza Bieniaka wizji ustroju drugiej monarchii piastowskiej, "Krakowskie Studia z Historii Państwa i Prawa" 2016, vol. 9, no. 4, pp. 471-486, DOI 10.4467/20844131KS.16.024.6324. Author's ORCID: 0000-0002-7256-410X.

${ }^{1}$ I would like to thank Professor Stanisław Grodziski, Dr hab. Maciej Mikuła and the reviewers for their careful reading of the manuscript and their helpful comments and suggestions. 
descendants held their provinces as governors on behalf of their senior (princeps) rather than hereditary rulers. ${ }^{2}$

Janusz Bieniak's concept of the $12^{\text {th }}$-century Piast state, based to a large extent on analogies with well-attested history of Early Rus', was generally accepted by scholars, ${ }^{3}$ yet it does rest on a fundamental contradiction. He claims that the brothers and sons of the princeps ruled their provinces as governors (like the junior Rurikids) without making clear how that could be squared with the function of the serving comes, i.e. the provincial governor acting as the grand duke's deputy. In the early 1980s, that did not look inconsistent for when Bieniak was working out his concept the office of the comes was still thought to be identical with that of a castellan in the $13^{\text {th }}$-century principalities. Only when that anachronistic assumption was corrected the inconsistency became all too obvious. ${ }^{4}$ If, as we now know, in the second Piast monarchy there was no autonomous network of castellans (castle-lords), it is hard to see why the Piast dukes were to function alongside other provincial governors. In other words, why should not they, like their Russian counterparts, act as governors themselves (in lieu of posadniks chosen from among the boyars)? The idea of administrative dualism, i.e. the co-existence of two high-ranking officials with overlapping competences in the same territorial domain, was common in medieval Germany - where royal (imperial) deputies, counts palatine (Pfalzgrafen) and burggraves or castle-lords (Burggrafen), functioned alongside princ-

2 Drawing on an earlier study by Jerzy Dowiat (Polska - państwem średniowiecznej Europy [Poland: A state of medieval Europe], Warszawa 1968, pp. 223-252), Janusz Bieniak presented his idea of Poland's constitutional order in the $12^{\text {th }}$ century in the first part of his major study of the medieval political elites, Polska elita polityczna XII wieku, Cz. 1: Tło działalności [Polish political elites of the 12 ${ }^{\text {th }}$ century: Part I: The background] [in:] Społeczeństwo Polski średniowiecznej [Polish medieval society], vol. 2, ed. S.K. Kuczyński, Warszawa 1982, pp. 29-61. Buttressed by further comments and supporting argumentation, this key concept was restated in each instalment of his study of medieval elites and in numerous other publications (especially J. Bieniak, Powstanie księstwa opolsko-raciborskiego jako wyraz przeksztatcania się Polski w dzielnicowa poliarchie [The creation of the Duchy of Opole-Racibórz as an example of Poland's transformation into a polyarchy of regions] [in:] Sacra Silentii provincia. 800 lat dziedzicznego księstwa opolskiego (1202-2002) [Sacra Silentii provincia: Eight hundred years of a hereditary Duchy of Opole (1202-2002)], ed. A. Pobóg-Lenartowicz, Opole 2003, pp. 37-81, with bibliography).

3 Cf. S. Gawlas, O ksztatt zjednoczonego Królestwa. Niemieckie wtadztwo terytorialne a geneza spoteczno-ustrojowej odrębności Polski [United Kingdom - what form? German territorial rule and the origin of Poland's social and constitutional identity], $2^{\text {nd }}$ ed., Warszawa 2000, p. 78. Cf. also the view shared by the reviewers of Jacek Osiński's (unsuccessful) attempt to refute Bieniak's concept of the Piast state, Tomasz Jurek (Review of Jacek Osiński, Statut Bolesława Krzywoustego, Wydawnictwo Avalon, Kraków 2014, "Roczniki Historyczne" 2015, vol. 81, p. 232, passim) and Mateusz Kosonowski (O ustawie sukcesyjnej Bolestawa Krzywoustego w kontrowersyjnym oświetleniu. W zwiazku z praca Jacka Osińskiego Statut Bolesława Krzywoustego, Wydawnictwo Avalon, Kraków 2014 [Bolestaw the Wrymouth's Statute of Succession: A polemic prompted by Jacek Osiński's study Statut Bolesława Krzywoustego, Avalon Publishing House, Kraków 2014], CPH 2015, vol. 67, issue 2, pp. 268-269).

4 T. Wasilewski, Poland's Administrative Structure in Early Piast Times. Castra Ruled by Comites as Centres of Provinces and Territorial Administration, "Acta Poloniae Historica" 1989, vol. 44, pp. 5-31; M. Cetwiński, Kasztelanowie i kasztelanie na Ślasku w XIII i XIV wieku [Castellans and castellania in Silesia in the $13^{\text {th }}$ and $14^{\text {th }}$ Centuries] [in:] Studia z dziejów średniowiecza polskiego i powszechnego, Acta Universitatis Wratislaviensis 1989, no. 979, series: Historia, vol. 69, pp. 3-20; S. Gawlas, O ksztalt zjednoczonego Królestwa..., pp. 74-75. See also: K. Fokt, Denuo de Legenicensi potestate: uwagi o znaczeniu Legnicy $w$ księstwie Bolestawa Wysokiego [Denuo de Legenicensi potestate: Some remarks about the importance of Legnica in Duchy of Silesia under Bolestaw I the Tall], "Śląski Kwartalnik Historyczny Sobótka" 2015, vol. 70, issue 2, pp. 5-6.

Artykuły - Articles 
es (Fürsten) and counts (Grafen $)^{5}$ - but virtually unknown in the monarchies of "New Europe".

That gives rise to the question: was the second Piast monarchy the only state in East Central Europe, apart from Germany, with a dual model of territorial administration?

\section{Model I: The duke and the count palatine (Pfalzgraf)}

One possible trace of the Piasts adopting the German institution of the territorial Pfalzgrafschaft could be a description in the anonymous Latin chronicle Gesta principum Polonorum (c. 1115) of Władysław I Herman, Duke of Poland, apportioning his realm between his two sons, with the exception of some principal royal castle towns (sedes Regni principales de manu sua non dimisit). ${ }^{6}$ Although many scholars have passed lightly over this passage, ${ }^{7}$ it does contain an unequivocal record of the introduction of a dual system of territorial administration: the ruler (the Prince) granted most of his lands to his sons, but retained control over some sedes Regni. The Chronicle names Cracow, Wrocław and Sandomierz as the principal sedes, ${ }^{8}$ of which - as another passage seems to suggest - Wrocław did not remain under Władysław Herman's direct rule, but became the capital of his younger son's domain. ${ }^{9}$ At the same time comes Wojsław resided in Wrocław where he was looking after the Grand Duke's younger son. The remaining part of his story suggests that his conduct was rather ambiguous (though not necessarily duplicitous) and looking after Bolesław was not his only responsibility, let alone his primary duty. Contrary to what we might expect given his function as custodian of young Bolesław, he did not attend his ward who decided to join his father's expedition

5 On the burggraves in general, see Th. Zotz, Burggraf [in:] Handwörterbuch zur deutschen Rechtsgeschichte, $2^{\text {nd }}$ ed., vol. 1, columns 766-768. On East German Burgrafschaften in the Age of the Salian and Hohenstaufen dynasties, see also the bibliography list in note 30 below. On the counts palatine, see I. Eberl, Pfalzgraf [in:] Lexikon des Mittelalters, vol. 6, columns 2011-2013; H.-W. Strätz, Pfalzgraf [in:] Handwörterbuch zur deutschen Rechtsgeschichte, $1^{\text {st }}$ ed., vol. 3, columns 1667-1670; and one of the latest studies of the office of the count palatine in Bavaria, Ch. Paulus, Das Pfalzgrafenamt in Bayern im frühen und hohen Mittelalter, Kommission für bayerische Landesgeschichte: Studien zur bayerischen Verfassungs- und Sozialgeschichte, Arbeiten aus der historischen Atlasforschung in Bayern, vol. 25, München 2007.

6 Galli Anonymi cronica et gesta ducum sive principum Polonorum, ed. and introd. by K. Maleczyński, "Monumenta Poloniae Historica”, series II, vol. 2, Kraków 1952, II, 7, p. 74.

7 Most notably by Janusz Bieniak who dismisses the idea that Władysław Herman would hold on to a few key castle towns out of hand. It would, he argues, lead to the unnatural division of "a integral unit formed by a castle town and its adjacent territory" and create "inconceivable administrative problems" (J. Bieniak, Polska elita ..., part 1, p. 20, note 44). However, in neighbouring Germany the prospect of such dire consequences did not deter Emperor Henry IV from strengthening the institution of the imperial palatine count and creating the Burggrafschaft of Meißen. Consequently, there seems to be no reason why the Piast grand dukes should find such a model of governance absurd or impracticable.

8 Galli Anonymi cronica..., II, 16, p. 83: Bolesław III Wrymouth entered Cracow and Sandomierz to extract an oath of loyalty from their residents.

9 Cf. G. Labuda, Władysław i Zbigniew. U genezy podziałów dzielnicowych w Polsce w drugiej połowie $X I$ wieku [Władystaw and Zbigniew: The root causes of Poland's fragmentation in the later $11^{\text {th }}$ century] [in:] Społeczeństwo Polski średniowiecznej [Polish medieval society], vol. 6, ed. S.K. Kuczyński, Warszawa 1994, pp. 17-18, note 23 . 
against the Czechs. According to Gallus Anonymus' Gesta Wojsław had probably not been informed about the Duke's campaign plans, nor was he around when Bolesław left and then unexpectedly returned to Wrocław. The comes, we are told, was all the while busy going about his official business (de servicio suo).$^{10} \mathrm{In}$ effect this evidence indicates that when Władysław I Herman signed over the southewestern part of his realm to his younger son he also appointed a comes, a person who had his full trust and whose duty was not just to take care of the infant prince, but also to look after the princeps' interests in Bolesław's domain. ${ }^{11}$

Unfortunately, the history of the second Piast monarchy offers no clear analogies to the situation discussed above, i.e. the cohabitation of a prince and a comes palatine (Pfalzgraf). The only other possible example of such an arrangement was Władysław II the Exile's appointment of Piotr Włostowic as his acting representative (comes) in Wrocław at a time when formally the government of Silesia was devolved to his elder son Bolesław I the Tall (Bolestaw I Wysoki) ${ }^{12}$ However, for the analogy to hold water it were necessary to prove that (1) during Bolesław's rule in Silesia Piotr Włostowic was actually the Duke of Poland's comes in Wrocław (and whether it meant his acting in the capacity of a voivode - which remains a much contested issue $)^{13}$ in parallel to his office of count palatine; (2) Piotr Włostowic's powers in Wrocław were in essence analogous to that of Wojsław's under Bolesław III the Wrymouth. To count as more than conjectures, each of the two theses needs good proof. So far the only direct evidence that can be cited in their favour is the Königsberger MS of the Chronica Polonorum (Chronicon Polono-Silesiacum) in which Piotr Włostowic is given the odd-sounding title comes tocius Polonie et pallacii Wratislaviensis (the sense of this phrase is unmistakable: it points to the cumulation of the office of Poland's count palatine and the function of the presumptive Pfalzgraf of Wrocław). ${ }^{14}$ That piece of evidence, for all it is worth, can hardly offer

10 Galli Anonymi cronica..., II, 16, p. 82.

11 On the dual role of comes Wojsław, see A. Krawiec, Król bez korony. Władysław I Herman, ksiąze polski [King without a Crown: Władysław I Herman, Duke of Poland], Warszawa 2014, p. 240.

12 The story of Bolesław the Tall actually taking over as the ducal governor of Silesia during his father's reign is based solely on indirect, though sufficienly strong, evidence. Cf. J. Bieniak, Polska elita..., part 1, pp. $42-44$.

13 Cf. a review of critical opinions in J. Spors, Wojewodowie Polski dzielnicowej w XII i XIII wieku: Przegląd wojewodów w kontekście ewolucji urzędu od godności nadwornej do urzędu ziemskiego [Voivodes of the Age of Poland's Fragmentation (12 th and 13 th centuries): An overview of voivodes in the context of the evolution of [the meaning of ] the term from a court office to a territorial governor], "Przegląd Historyczny" 1991, vol. 82, issue 3-4, p. 363; and J. Bieniak, Polska elita polityczna XII wieku, cz. IV B: Dwa możnowladztwa - starszy $i$ nowi [Polish political elites of the $12^{\text {th }}$ century, Part IV B: The old and the new powerbrokers] [in:] Spoleczeństwo Polski średniowiecznej: Zbiór studiów [Polish medieval society: A collection of studies], vol. 12, ed. S. Górzyński, Warszawa 2012, pp. 30-31 (with further primary and secondary bibliography). What has been established beyond any doubt is Piotr Włostowic’s functioning as count palatine in the court of Duke Bolesław IV the Curly (cf. especially J. Spors, Wojewodowie Polski dzielnicowej..., p. 364; and J. Wenta, O stróżach ,testamentu” Bolesława Krzywoustego [The custodians of the Bolesław the Wrymouth's 'Testament'] [in:] Społeczeństwo Polski średniowiecznej [Polish medieval society], vol. 8, ed. S.K. Kuczyński, Warszawa 1999, pp. 100-105).

14 Kronika Polska (Chronica Polonorum), ed. L. Ćwikliński, "Monumenta Poloniae Historica”, vol. 3, Lwów 1878, p. 628. The claim that Piotr Włostowic may have combined the offices of count palatine and governor in Wrocław is discussed in J. Spors, Wojewodowie Polski dzielnicowej..., pp. 363-364. The objection raised by J. Bieniak (Polska elita polityczna XII wieku, Part III A: Arbitrzy ksiażat-krąg rodzinny Piotra Włostowica [Polish political elites of the $12^{\text {th }}$ century, Part III A: Arbiters of princes - Piotr Włostowic's fam-

Artykuły - Articles 
a solid base, let alone proof, of further claims. In fact, the claim that Władysław II the Exile established a dual administration in Wrocław, following Bolesław the Wrymouth's model of government (as reconstructed above), cannot be advanced without a thorough re-examination of the history of Poland and Silesia in 1138-1145 and the life of Piotr Włostowic. That, however, goes beyond the scope of this article.

\section{Model II: The prince and the governor}

Another model of co-existence in the provincial capital of the junior duke and the central-government official (governor) has been used in the narrative of the 1093 rebellion which successfully reinstated the banished Zbigniew, Władysław Herman's first-born son, as heir apparent. According to the Gallus Anonymus' Gesta, Zbigniew was welcomed in Wrocław by comes nomine Magnus, and some time later his authority over the province of Silesia was legitimized by his father. That created a rather odd situation: an acting provincial governor had to co-exist with a Piast dynast. ${ }^{15}$ In comparison with the cohabitation in Wrocław of Bolesław and comes Wojsław, discussed above, the post-1093 alignment of Magnus and Zbigniew was characterized by a greater degree of decentralization, or, to borrow Gallus Anonymus' turn of phrase, Duke Władysław I Herman sedem Wratislaviensem de manu sua dimisit. While it is highly improbable

ily circle] [in:] Spoleczeństwo Polski średniowiecznej [Polish medieval society], vol. 4, ed. S.K. Kuczyński, Warszawa 1990, p. 33), who argues that such a cumulation would make it impossible to exercise "either one of the those offices or the other" is hardly persuasive. At that time such offices involved not only executive functions, but were also, or even primarily, dignities signalling high rank (cf. Th. Zotz, Im Amt und Würden: Zur Eigenart ,, offizieller”. Positionen im früheren Mittelalter, “Tel Aviver Jahrbuch für deutsche Geschichte” 1993, vol. 22, pp. 1-23). It seems most improbable that Piotr Włostowic's promotion to the rank of count palatine would make him abandon his Wrocław post, a position he had worked hard to build up and consolidate through, among others, setting up foundations on an unprecedented scale.

15 Galli Anonymi cronica..., II, 4, p. 71. Unfortunately, the chronicler fails to define the status of Zbigniew in unambiguous terms. As a result quite a number of historians have been downright skeptical of the claim that the legitimization of Zbigniew as heir apparent was followed by his instalment as Duke of Silesia (cf. for example H. Łowmiański, Poczatki Polski. Polityczne i społeczne procesy kształtowania się narodu do poczatku wieku XIV [The emergence of Poland: Political and social aspects of the nation-building processes until the $14^{\text {th }}$ century], vol. IV, part 1, Warszawa 1985, pp. 117-119; and K. Benyskiewicz, Wtadystaw Herman. Książę Polski 1079-1102 [Władystaw Herman: Duke of Poland, 1079-1102], Kraków 2014, p. 143). However, the facts at the core of the chronicler's record - the legitimation of Zbigniew's filial rights by his father, his settling down in Wrocław, and his plans of making Silesia his base (dashed by the desertion of his allies) - carry the inescapable implication that Zbigniew had the status of a junior duke. Cf. among others R. Grodecki, Zbigniew książę Polski [Zbigniew, Duke of Poland] [in:] Studja staropolskie. Księga ku czci Aleksandra Brücknera [Studies on Old Poland: A Festschrift in Honour of Aleksander Brückner], Kraków 1928 , p. 86; K. Maleczyński, Śląsk w okresie od schyłku IX do połowy XII wieku [Silesia from the turn of the $9^{\text {th }}$ century until the middle of the $12^{\text {th }}$ century] [in:] Historia Ślaska [History of Silesia], vol. 1: Do roku 1763 [Prior to 1763], part 1: Do polowy XIV w. [Prior to the mid-14 ${ }^{\text {th }}$ century], ed. K. Maleczyński, p. 210; J. Bieniak, Polska elita..., part I, p. 46; G. Labuda, Władysław i Zbigniew..., pp. 14-16, note 18; R. Żerelik, Dzieje Śląska do 1526 roku [History of Silesia prior to 1526] [in:] Historia Ślaska [History of Silesia], ed. M. Czapliński, Wrocław 2002, p. 43; and Z. Dalewski, Modele władzy dynastycznej w Europie Środkowo-Wschodniej we wcześniejszym średniowieczu [Models of dynastic government in Central and Eastern Europe in the Early [High] Middle Ages], Warszawa 2014, p. 254 (with further references). 
that the instalment of Zbigniew as junior duke in the Silesian capital would result in the demotion or reducing the competences of the Władysław Herman's governor, it is also hard to imagine that the status of new junior duke would be lower than that of Magnus. This shows how different this situation was from the apparently similar instalment in Wrocław of the young Bolesław the Wrymouth. In the former case Władysław I Herman practically let go the reins of power. He did not appoint an official (comes) to look after his elder son, and, moreover, he had to accept that Silesia fell under the dual rule of Zbigniew and Magnus, de facto acting fairly independently of the central government. In practice, decentralization meant the devolution of the treasury for - if Magnus retained his position - the newly created duke who had to be provided with at least a portion of the revenues of the Duchy of Silesia that had been collected for the duke senior. ${ }^{16}$

Apart from that one example in so called Gallus Anonymus' Gesta) discussed above it is hard to find more accounts of a relationship between prince (junior duke) and comes (representative of duke senior) that would fit Model II. In fact, though, there seems to be just one more good historical example which exhibits the structural characteristics of Model II. It is a late $12^{\text {th }}$ century story, which features the "cohabitation" of Leszek Bolesławowic, the son of Bolesław IV the Curly (Bolesław Kędzierzawy), and comes Żyra, governor of Mazovia. Żyra enters the scene as a governor (comes) of Mazovia (probably as early as 1161); ${ }^{17}$ then during the first reign of Mieszko III the Old (Mieszko III Stary) and in the early years of the reign of Kazimierz II the Just (Kazimierz II Sprawiedliwy) he combined the office of governor with the guardianship of the minor prince; and finally acted as voivode (count palatine) of Mazovia in the entourage of the adult Duke Leszek. ${ }^{18}$ To assume that formally his position remained unchanged in the course of three successive reigns would certainly be too hasty. However, if the career of this Mazovian nobleman began with the governorship of a province and in its next phase involved the guardianship of a minor prince, it certainly fits the pattern set out in Model II.

16 We can find no reference in the contemporary sources to the division of provincial revenues between the duke senior or his governors and the junior dukes with the appropriate titles. Cf. K. Modzelewski, Chłopi $w$ monarchii wczesnopiastowskiej [Peasants in the early Piast monarchy], vol. 1 of Chłopi w społeczeństwie polskim [Peasants in Polish society], ed. Cz. Madajczyk, Wrocław 1987, p. 143, note 29. Yet, some kind of transfer mechanism must have functioned in Poland prior to 1177 not unlike contemporary fiscal arrangements in other countries, especially Germany, Hungary, Croatia and Rus'. Cf. K. Modzelewski, Organizacja gospodarcza państwa piastowskiego: X-XIII wiek [The economic system of the Piast state in the $10^{\text {th }}-13^{\text {th }}$ centuries], $2^{\text {nd }}$ ed., Poznań 2000, pp. 92-94 and 152; M. Font, Im Spannungsfeld der christlichen Großmächte. Mittel- und Osteuropa im 10.-12. Jahrhundert, Herne 2008, pp. 137-139; and М.Ф. Котляр, В.М. Ричка, Княжий двір Південної Русі X-XIII ст. [Princely court of Southern Rus' in the $10^{\text {th }}-12^{\text {th }}$ centuries], Kyiv 2008, pp. 194-195). On the funding arrangements of the earliest Polish bishoprics, see K. Modzelewski, Organizacja..., pp. 93-94, passim; for data concerning the Age of Fragmentation, see F. Dąbrowski, Studia nad administracja kasztelańska Polski XIII wieku [Studies of Poland's castellan administration in the $13^{\text {th }}$ century], Warszawa 2007, p. 44.

17 Cf. Liber formularum ad ius canonicum spectantium, ex actis Jacobi de Kurdwanow episcopi Plocensis maxima parte depromptarum, ed. B. Ulanowski, “Archiwum Komisji Prawniczej”, vol. 1, no. 29 , p. 35.

18 His advancement is reflected in the change of nomenclature in Book IV of Wincenty Kadłubek's Chronicles of the Kings and Princes of Poland. In Chapter 8 Żyra is called preses provinciarum, but later in Chapter 13 procurator Lestconis ac militie princeps (Cf. Magistri Vincentii dicti Kadtubek Chronica Polonorum, ed. M. Plezia, "Monumenta Poloniae Historica”, series II, vol. 9, Kraków 1994, pp. 147 and 155. Cf. also J. Bieniak, Polska elita..., part I, p. 19; and part IV B, pp. 33 and 38).

Artykuły - Articles 
In both these cases Model II has been applied to a situation where a junior duke of the Piast dynasty is paired off with a figure of authority in a provincial setting (Zbigniew and Magnus, Leszek Bolesławowic and Żyra). One may wonder if these situations resulted from the operation of chance, or to put it differently, represented one-off solutions to certain problems brought up by the course of events. Yet, it would be wrong to write them off as insignificant. The idea of "dual governorship" could, paradoxically, appear attractive to the senior dukes for it allowed them to maintain a certain balance at the top, i.e. provide a title and a source of income for the junior duke(s) - even at the cost of the grand duke's share - without taking away lucrative territorial posts from the most powerful, and potentially dangerous, members of the political elite. This reasoning may well have been behind a document issued in 1139 by Bishop Robert of Wrocław. While mentioning the younger sons of Bolesław III the Wrymouth and their possessions (duchies), it calls them co-regents of the state. ${ }^{19}$ It cannot be ruled out that this triumvirate participated jointly in a portion of the provincial revenues earmarked for the central government; such a system enabled the maintenance of governors recruited from the political elite and acting on behalf of the senioral centre of power. ${ }^{20}$ In effect, it may be surmised that the "dual governorship" Model II was more common than it is possible to make out at this stage of research.

\section{Model III: The prince as governor}

Among the dozen or so examples of the co-existence of princes and comites collected by Janusz Bieniak ${ }^{21}$ there are some that fit neither of the two models that have been presented above. The difficulties in classifying the individual cases have their cause in the paucity and obliqueness of the sources. Our data base contains for the most part

19 Schlesisches Urkundenbuch, vol. 1: 971-1230, eds. J.J. Menzel, H. Appelt, rev. H. Appelt, Köln-Graz 1963 (henceforth: SUB), no. 19: Boleslao tercio Polonie principe defuncto, regnantibus pro eo filiis eius Wladislao in Cracouia, Boleslao in Mazouia, Misicone in Poznania. This document was probably written in 1149, but it reflects with remarkable accuracy the realities of c. 1139 (cf. the critical commentary of the SUB editors in vol. 1). For assessments that give more weight to the autonomy of the junior dukes than their status as deputies, see H. Łowmiański, Rozdrobnienie feudalne Polski w historiografii naukowej [Poland's feudal fragmentation in academic historiography] [in:] Polska w okresie rozdrobnienia feudalnego [Poland in the Age of Feudal Fragmentation], ed. H. Łowmiański, Wrocław 1973, pp. 31-32; J. Spors, Podziat dzielnicowy Polski wedlug statutu Bolesława Krzywoustego ze szczególnym uwzględnieniem dzielnicy seniorackiej [Poland's devolution in Bolestaw the Wrymouth's Statute of Succession and the seniorate province], Słupsk 1978, p. 114. Cf. also the polemic of J. Bieniak, Polska elita ..., part I, pp. 49-50.

20 We have no reliable information about the participation of junior dukes in the revenue designated for the duke senior during the reign of Bolesław IV the Curly. However, what we do know is that the latter kept the privilege of mint to himself, but there are some indications that he shared with his brothers some of the revenue from the Wieliczka salt mine (in the senioral province). Cf. M. Biniaś-Szkopek, Bolesław Kędzierzawy [Bolesław the Curly], Poznań 2014, pp. 239-241.

21 He presented the relevant data in his catalogue of officials of the $12^{\text {th }}$ and $13^{\text {th }}$ centuries in the Appendix to the last part of his study of Polish political elites of the $12^{\text {th }}$ century, part IV B (see note 13 above). That list does not include the casus of the parallel functioning in Wrocław of Bolesław the Tall and Piotr Włostowic (J. Bieniak expressly excluded it, cf. J. Bieniak, Polska elita ..., part III A, p. 33). The case has been discussed above. 
$12^{\text {th }}$-century lists of names, often loosely attached to later forgeries. Their exegesis depends heavily on the researcher's assumptions and interpretive key. The sensitivity of those instruments depends in turn on further progress in the study of Poland's $12^{\text {th }}$-century political and constitutional history. But even without additional, in-depth study it is possible to distinguish another, third model of co-existence of Piast princes du sang and state officials (governors). It could be called a "pure" model of government in which the latter function was handed over to the junior dukes (who had thus acquired the status of comites, or, to use a Ruthenian analogy, posadniki).

Gallus Anonymus' account of the old Duke Władysław's apportionment would have been straight enough were it not for the somewhat different treatment of his two sons. Bolesław's portion did not include its capital city Wrocław, which, we are told, his father de manu sua non dimisit, while no reservations were attached to Zbigniew's rights over the capital city of his province (presumably Gniezno). ${ }^{22}$ In effect, it meant that Zbigniew became governor of the northwestern province (Wielkopolska). His position was therefore more comfortable than that of his younger brother who had to put up with a comes (guardian). ${ }^{23}$ The chronicler tries to make light of this imbalance by embellishing the importance of the southern sedes Regni - he calls them principales - and thus to justify Władysław Herman's decision to have direct control over Wrocław (through his representative, comes Wojsław). In a similar way, after his father's death and his brother's victory in civil war, Zbigniew held Mazovia as an ordinary comes, i.e. sicut miles, non ut dominus. ${ }^{24}$

It is quite possible that the next generations of the Piasts - before the unravelling of the monarchy - resorted to this model of government. So for instance historians have noted that unlike Bolesław IV the Curly and Mieszko III, their younger brother Henry's lordship over the Province (Land) of Sandomierz was designated dominium rather than ducatus. The different legal titles most probably encode differences of their holders' rank and status (here the elder versus the younger brothers). ${ }^{25}$ After his return from ex-

22 Gerard Labuda denies the accuracy of Gallus Anonymus account, but does not give any reason why we are to believe it to be false (cf. Władystaw i Zbigniew..., p. 20). Equally unconvincing is a similar attempt to reinterpret the story of the two brothers in Karol Maleczyński's study Bolesław Krzywousty. Zarys panowania [Bolesław the Wrymouth: An outline history of his reign], Kraków 1947, pp. 23-24. Maleczyński assumes that Gallus had a special interest in Bolesław and therefore mentioned the fact of his not getting control over Wrocław but passed over a similar restriction with regard to Zbigniew (presumably out of sympathy with the latter). This string of conjectures seems both unfounded and improbable. After all, the logic of the chronicler's narrative suggests the opposite. Gallus Anonymus tries to suggest that the idea of the sedes regni principales did not put Bolesław at a disadvantage (cf. Book II, Ch. 7), but rather put him in better position (so Book II, Ch. 8). At the same time, though, the narrator's rhetoric opens up a different picture. Whereas the first apportionment left the younger brother worse off, the provisions for the devolution of titles and land after Władysław I Herman's death were fair and just.

23 This disparity was noted by Roman Grodecki (Zbigniew..., pp. 89-90). He was also absolutely right about the bias of the Gallus Anonymus' Gesta, but not quite so in his assessment of the scope of the junior dukes' territorial possessions. For a critical view of Grodecki's approach, see K. Maleczyński, Bolesław Krzywousty..., pp. 23-24 (for a polemic with the latter, see note 21); and A. Krawiec, Król bez korony..., pp. 239-240.

24 Galli Anonymi cronica..., II, 38, p. 109.

25 T. Lalik, Sandomierskie we wcześniejszym średniowieczu. Prowincja, księstwo, województwo [Land Sandomierz in the Early Middle Ages: Province, duchy, viovodship] [in:] Studia sandomierskie. Materiaty do dziejów miasta Sandomierza i regionu sandomierskiego [Studies on Sandomierz. Material to the history 
ile, Bolesław the Tall, too, must have ruled Silesia as a dominium for as far as we know there was no other comes in Wrocław in his time. In this case we can look for cues not only in the records but also in the peculiarities of Silesia's institutional history. One such peculiarity is the prominent role of the office of the camerarius, which was the highest court dignity in fact identical with that of count palatine, but probably originated from the office of the chamberlain at the ducal court. ${ }^{26}$ In other parts of Poland the dignity of palatine was descended from the office of provincial governor, as e.g. in Mazovia under Leszek Bolesławowic. There comes Żyra held the post of governor which was later transformed into the office of a palatine (voivode). Moreover, in Silesia the duke senior continued to exercise far reaching power until 1177 as was shown in 1175 by his treatment of the Cistercian Abbey at Lubiąż (Kloster Leubus) as his own foundation and its true founder, Duke Bolesław I the Tall, as the monks' advocatus (Kirchenvogt). ${ }^{27}$

\section{Model IV (hypothetical): Princes as de facto independent rulers}

The three structural models presented above do not take account of all the ways in which the junior Piast dynasts were made to take up responsibilities in the apparatus of territorial government. One scenario which is obviously missing from this array is the situation when a junior duke were to be endowed with significantly broader competences than those of an ordinary governor and would take over power in his province in the absence of a governor (comes) appointed by the princeps. The sources from the time of the second Piast monarchy provide no watertight historical casus to illustrate such a configuration, yet the idea itself was entirely at odds with contemporary realities. After all, in 1102-1107 Poland was de facto a diarchy, or a duumvirate, i.e. it was co-ruled, by Zbigniew and Bolesław. If that was possible, why not allow another hypothetical model (Model IV) in which the dukes accept the princeps' primacy in general, as a matter of form, but behave like any head of an independent state? Actually, this formula could be an apt description of the status of Mieszko III the Old during the seniorate of Bolesław

of the city of Sandomierz and its region], ed. T. Wąsowicz, J. Pazdur, Warszawa 1967, pp. 70-75. Cf. also A. Teterycz-Puzio, Henryk Sandomierski: polski krzyżowiec (1126/1133 - 18 X 1166) [Henryk of Sandomierz: A Polish crusader (1126/1133-18 October 1166], $2^{\text {nd }}$ ed., Kraków 2015, pp. 55-59 (with further references to sources and bibliography lists). For a skeptical view of the differences in the formal status of Henryk and his elder brothers, see M. Biniaś-Szkopek, Bolesław Kędzierzawy..., pp. 201-202.

${ }^{26}$ On the unique characteristics of Silesia and the office of the comes camerarius at ducal courts, see J. Spors, Uwagi nad geneza urzędu wojewody dzielnicowego w Polsce XII-poczattku XIII wieku [Origins of the office of the provincial voivode in Poland (12 $2^{\text {th }}$-early $13^{\text {th }}$ centuries)], "Przegląd Historyczny" 1991, vol. 82, issue 2, pp. 205-206; idem, Ze studiów nad urzędami w Polsce XI i XII w. (wojewoda, komornik, podkomorzy) [Studies on the offices in Poland in the $11^{\text {th }}-12^{\text {th }}$ centuries (voivode, camerarius, subcamerarius)], CPH 1992 (publ. 1993), vol. 44, issue 2, pp. 35-36.

27 Cf. SUB, vol. 1, no. 49. Cf. also J. Bieniak, Polska elita ..., part 1, p. 60. For Bieniak the text of the foundation document belongs to a tradition of solemn affirmations of the rights and the superior status of the duke senior (Mieszko III the Old). In his reading of the document, Przemysław Wiszewski questions the continuity of the tradition evoked by Bieniak and argues that senioral primacy over Silesia had been rather ineffective until Mieszko III's determined effort to restore it. Cf. P. Wiszewski, Mieszko III Stary i jego czasy [Mieszko III the Old and his times], Wrocław 2002, p. 7. 
IV the Curly - it could, perhaps, but there is no way to reach certainty on this point one way or the other. ${ }^{28}$ And, at any rate, the modus operandi just described could have resulted from a single decision, but it could also have been the outcome of a longer process that was triggered by an "ordinary" governorship (Model III).

\section{Conclusion and recommendations}

The foregoing analysis shows that the constitutional reality of the second Piast monarchy was far more complex than it is usually believed to be, and Janusz Bieniak's concept of the junior Piast dukes' devolved rule needs to be developed and expanded. The evidence of Gallus Anonymus' Gesta indicates that as early as the end of the $11^{\text {th }}$ century (i.e. the late years of Władysław Herman's rule) there were already in place three distinct models of funding the junior dukes. They are as follows: (1) Model I, or dual administration, where the the Piast prince is accompanied by a comes whose function is to represent the interests of the duke senior; (2) Model II, or double-track administration, where the Piast prince functions alongside a separately appointed comes (provincial governor); the funding for the prince probably comes from a portion of the revenue collected for the duke senior; and (3) Model III, or uniform (single-track) administration, where all powers at the regional level are concentrated in the hands of one person: the prince du sang is vested with all the competences of a governor (as in Rus'). These models have been constructed in the process of inductive interpretation of the historical record set down in Poland's earliest chronicle; in the next step, their operation have been projected (usually in the conjectural mode) onto situations from a later period, which is better documented though often enough the sources do not offer sufficient insight into constitutional matters. At the same time it is hard to brush off the impression (which can harden into an objection) that the constructs abstracted from Gallus Anonymus' Gesta are in fact individual cases illustrating concrete problems of territorial administration and solutions, each of them determined by a peculiar set of circumstances. Be that as it may, I am convinced my extrapolations make sense and can be treated as "models", a term chosen not only for its appropriateness but also because it should help put the problem discussed in this article on the agenda on medieval studies. More research is need to explore all aspects of the employment of junior dukes in the provincial administration in the $11^{\text {th }}-12^{\text {th }}$ centuries, i.e. whether there were any regular or formalized ways of doing it, what were the differences between the individual rulers enacting that practice, or, last but not least, if it was inspired, case by case, by some external factors.

The procedure covered by the first model may have been inspired by German examples. That the political practices of the Salian emperors had some influence on the conduct of Władysław Herman and his close advisor, count palatine Sieciech, was rightly noted by Sławomir Gawlas in his groundbreaking study of the evolution of Poland's political system in the $11^{\text {th }}-13^{\text {th }}$ centuries. One of the concomitants of the policy aimed

28 The question whether Mieszko had a special status under the rule of his elder brother is discussed by Magdalena Biniaś-Szkopek in Bolesław Kędzierzawy..., pp. 184-189. 
at strengthening the power of the Duke Senior was the undermining of the position of the territorial comites by the creation of a tier of officials (pristaldi) loyal to the central authority that appointed them. ${ }^{29}$

However, it would not be right to assume that in the particular case of "cohabitation" of Duke Bolesław and comes Wojsław the latter was a pristaldus. Wojsław was a powerful noble while the pristaldi, judging by the references in Gallus' Gesta, were men of lower rank. Bolesław's rule in Silesia should be treated as the more complicated balancing act in so far as his powers were curtailed too by the alienation of sedes regni Wratislaviensis. One may wonder whether the very idea of putting a curb on the younger duke had in it the seeds of a backlash, though eventually Bolesław and Zbigniew rose up against their father, or whether the initial success of the scheme was due to Bolesław's young age.

Another moot point worth researching is the question if and to what extent this model, which no doubt strongly promoted the interest of the duke senior, was resorted to in the ominous late phase of second monarchy, i.e. the fifth and sixth generation of the historic Piasts. The facts suggest that no use was made of it, or if there was effort to use it not much came of it (as shown by the case of Piotr Włostowic, assuming that he did function as comes palatine in Wrocław). It all boils down to one inescapable conclusion: the senior princes of the $12^{\text {th }}$ century had only limited control over the devolved provinces. This assessment is confirmed by the lack of unequivocal evidence of the reception in Poland prior to 1177 of the institution of the Burggrafschaft. In Germany under the last Salians and the first two Staufen it became an important instrument of consolidating royal power. ${ }^{30}$ The role of the Burggrafschaft was even greater in the eastern parts of the Empire (east of the River Saale) - not only did it make estate management more efficient but also undercut the power of the Markgrafen through the creation of a mosaic of enclaves where the king ruled supreme.

In spite of great attractiveness of this administrative innovation, its Polish equivalent, the institution of the castellany (headed by a kasztelan, Lat. castellanus, or lord of a castle), did not make its appearance in the Piast-ruled lands until the turn of the $12^{\text {th }}$ century. ${ }^{31}$ We can find only few enigmatic records that seem to indicate the presence of castellans in Cracow $^{32}$ and Kruszwica ${ }^{33}$ in the end phase of the second Piast monarchy,

29 S. Gawlas, O ksztatt zjednoczonego Królestwa..., pp. 73-74. Cf. also A. Krawiec, Król bez korony..., pp. 189-194; and K. Benyskiewicz, Władysław Herman..., p. 139.

30 On the early phase of the East German Burggrafschaften, see W. Schlesinger, Zur Gerichtsverfassung des Markengebiets östlich der Saale im Zeitalter der deutschen Ostsiedlung, "Jahrbuch für die Geschichte Mittel- und Ostdeutschlands" 1953, no. 2, pp. 59-62; H. Helbig, Der Wettinische Ständestaat: Untersuchungen zur Geschichte des Ständewesens und der landständischen Verfassung in Mitteldeutschland bis 1485, "Mitteldeutsche Forschungen", vol. 4, Münster-Köln 1955, pp. 204-273, passim; and A. Thieme, Die Burggrafschaft Altenburg: Studien zu Amt und Herrschaft im Übergang vom hohen zum späten Mittelalter, "Schriften zur Sächsischen Landesgeschichte”, vol. 2, Leipzig 2001, pp. 152-163.

31 The references to Lubusz (Lebus), Gniezno and Cracow in sources from the 1190 s are listed in J. Bieniak, Polska elita..., part IV B, pp. 35-37. The earliest Silesian documents that mention the local castellans come from the first decades of the $13^{\text {th }}$ century, cf. SUB, vol. 1, nos. 77, 83, 87, 88, 93, 116 and 117.

32 Cf. J. Bieniak, Polska elita..., part IV B, p. 37; Urzędnicy małopolscy XII-XV wieku: Spisy [A Register of Officials in Małopolska (12 th $15^{\text {th }}$ centuries)], eds. A. Gąsiorowski, J. Kurtyka et al., Wrocław 1990, nos. 108-109, pp. 58-59 (and further references).

33 The case of Kruszwica is particularly hard to entangle as the name "Piotr Wszeborzyc, Voivode of Kujawy and Castellan of Kruszwica" appears on list which can be found in two different sources. One of 
i.e. under Bolesław IV the Curly and during the first reign of Mieszko III the Old. ${ }^{34}$ The first - rather feeble and, as it turned out, ephemeral - phase of its reception in Poland took place before the constitutional crisis of 1177-1180 and affected only the domain of the duke senior. No castellanies were founded at that time in the lands ruled by the junior dukes. The next phase, however, saw a complete reversal as all the castellans mentioned in the sources from the $13^{\text {th }}$ century were installed by the junior dukes. The failure of the senior dukes of the fifth, sixth and seventh generation of Piast dynasty to push through their plans of strengthening the centre of government should come as no surprise. Those who tried to impose their will on others (Władysław I Herman, Władysław II the Exile, Mieszko III the Old) failed dismally, while those who relied on a consensual approach and took care not to antagonize too much their relatives or political strongmen were able to hold on to the throne and make their plans work.

One the means at their disposal was the procedure of Model II, ceding the administration of a devolved province to a junior duke and a comes who represented the central government. This arrangement came at a price - the senior duke's partial loss of control and revenue.

More research is needed to answer what at this point is an open question, i.e. to what extent this model was adapted into the political practice of the $12^{\text {th }}$ century. It seems that its best use as an instrument of Polish politics at that time would be to prop up and conserve a labile equilibrium between the dynasts and the noble elite. ${ }^{35}$ Bearing that in mind, we cannot rule out that the Piast rulers would have seen things similarly and used this model as a means to maintain their power. The third model, with its concentration of

them is Liber fraternitatis et liber mortuorum Abbatiae Sancte Mariae Lubinensis (cf. Ksiega bracka i nekrolog opactwa Panny Marii w Lubiniu, ed. and introd. by Z. Perzanowski, "Monumenta Poloniae Historica", series II, vol. 9, part 2, Warszawa 1976, p. 13) and the other a forged document from Mogilno, purportedly issued by Mieszko III (cf. M. Kosonowski, Dokumenty księżnej Salomei i księcia Mieszka Starego dla klasztoru Benedyktynów w Mogilnie z XVII-wiecznego kopiariusza Archiwum Krakowskiej Kapituły Katedralnej. Studium krytyczne i edycja tekstów [Documents of Duchess Salomea and Duke Mieszko the Old [addressed to] the Benedictine Abbey at Mogilno [as copied] in a $17^{\text {th }}$-century cartulary of the Cracow Chapter Archives: A critical study and critical edition of the texts] [in:] Signa. Studia i szkice z nauk pomocniczych historii. Prace dedykowane Profesorowi Zenonowi Piechowi w sześćdziesiata rocznice urodzin [Signa. Studies and essays in auxiliary sciences of history: A Festschrift in Honour of Professor Zenon Piech on his $60^{\text {th }}$ birthday anniversary], eds. A. Marzec, M. Starzyński, „Studenckie Zeszyty Historyczne Koła Naukowego Historyków Studentów UJ", no. 21, Appendix 1, pp. 48-58, Kraków 2014). The list in the Liber fraternitatis, which bears the date 1176, may well be authentic (for a vigorous defence of its authenticity, see K. Mosingiewicz, B. Śliwiński, Rycerstwo polskie z końca XII w. w falsyfikacie Kazimierza Sprawiedliwego [Polish knighthood of the late $12^{\text {th }}$ century in the forged document of Kazimierz the Just], "Kwartalnik Historyczny" 1981 , vol. 88, issue 3, p. 720 and passim), whereas the majority of scholars who examined the Mogilno forgeries dates that list back to the 1190s (for a survey of critical opinions and the author's own solution of the problem, see M. Kosonowski, Dokumenty..., pp. 40-44). As things stand, neither option can be ruled out. Nonetheless, as the date 1176 is directly attached to the list in the source, the weight of that record must not be underestimated.

34 The claim that there was at that time yet another castellany, namely Wizna (Castrum Wizna), is highly implausible. For a scrutiny and a refutation of that claim, see G. Białuński, Wizna na pograniczu polsko-pruskim w czasach księcia Bolesława Kędzierzawego [Wizna on the Polish-Prussian border during the reign of Bolesław IV the Curly] [in:] Pogranicze polsko-pruskie i krzyżackie. Materiaty z konferencji naukowej Górzno 1-2 czerwca 2002 r. [The Polish-Prussian and Polish-Teutonic Order borderlands: Conference proceedings, Górzno 1-2 June 2002], ed. K. Grążawski, Włocławek-Brodnica 2003, pp. 267-271.

35 This problem is at the core of the discussion in S. Gawlas, O ksztatt zjednoczonego Królestwa..., esp. pp. 74, 79, and passim.

Artykuły - Articles 
devolved power in the hands of one person, i.e. the replacement of members of the noble elite (posadniki) by Piast princes $d u$ sang, has none of those advantages. It leaves the ruler no room for maneuver, i.e. in the real world of the $12^{\text {th }}$ century it would not allow the duke senior to hold out rewards to buy the loyalty of the noble elite, nor would it let him use those noblemen qua governors to hold in check his own family, the junior dukes. For the latter, it goes without saying, the third model would be most attractive.

Janusz Bieniak is basically right in saying that government by deputy (namiestnictwo), at times made less transparent by the installation of a provincial governor (comes), was the key feature of the administration of the provinces under the second Piast monarchy. This characterization corresponds to Model II and III of the typology presented in this article. However, the chances that we will ever know on how many occasions the prince and the comes formed a provincial duumvirate are practically nil as our main source for $12^{\text {th }}$-century provincial elites are official registers, i.e. lists of names stripped of any additional information. Consequently, the modern reader is left to guess whether the person listed next to the junior duke was an office-holder and what that office may have been. Depending on the authority we choose to follow, Józef Spors, Janusz Bieniak or Tadeusz Lalik, we will identify that person as the duke's camerarius, comes castellanus or comes palatinus respectively. Be that as it may, there can be no doubt that the dominant role in the political practice of $12^{\text {th }}$-century Poland was played by Model II and III. This conclusion should at last dispel the ghost of "Piast despotism" which has been haunting Polish medieval studies. Like their counterparts in Germany and Bohemia, the Piast senior dukes were compelled to develop a consensual style of government ${ }^{36}$ in alliance with a social elite made up of other members of the ruling family ${ }^{37}$ and the most powerful noblemen. ${ }^{38}$

36 The concept of consensual government ("konsensuale Herrschaft") was introduced by Bernd Schneidmüller in his study of the German historical experience (B. Schneidmüller, Konsensuale Herrschaft. Ein Essay über Formen und Konzepte politischer Ordnung im Mittelalter [in:] Reich, Regionen und Europa in Mittelalter und Neuzeit. Festschrift für Peter Moraw, ed. P.-J. Heinig, Berlin 2000, pp. 53-87). For the development of that model in the political practice of Germany (the Holy Roman Empire) in the $11^{\text {th }}-12^{\text {th }}$ centuries, see J. Schlick, König, Fürsten und Reich (1056-1159): Herrschaftsverständnis im Wandel, Mittelalter-Forschungen, vol. 7, Stuttgart 2001. It would not be possible to write an equally comprehensive study of that aspect of Polish history due to the paucity of sources for the Age of the Piasts. Nevertheless, Janusza Bieniak's in-depth studies of $12^{\text {th }}$-century Polish noble elites and their relations with the ruling dynasty leave hardly any doubt that powerful noblemen who were no relatives of the Piasts were to some extent involved in the business of ruling the country. Finally, let me bring in a quote from Karol Modzelewski, the leading proponent of the view that the key characteristic Central and Eastern European states in the $11^{\text {th }}$ and $12^{\text {th }}$ centuries was a strong ducal government and an economically weak nobility. In his study of Poland's economy in the Age of the Piasts Modzelewski admits that "those monarchies were closer to an aristocratic oligarchy than despotism" (K. Modzelewski, Chłopi..., p. 159).

37 The elites of the first and second Piast monarchy were aware of claims of all the members of ruling family (clan) to have a share in power. How that issue functioned in the consciousness of the ruling elite and other contemporary power brokers is the subject of an incisive study by Zbigniew Dalewski (Modele władzy dynastycznej...). Cf. also a telling quote from J. Bieniak, Polska elita ..., part I, p. 48: "They [the Piast dynasts] were generally believed to have a best claim to co-rule (domini naturales); having castellans [i.e. comites, $\mathrm{KF}$ ] as governors of the main towns was only a stopgap solution necessitated by the lack of a Piast".

38 On the ambitions and the importance of the Polish nobles of the late $11^{\text {th }}-12^{\text {th }}$ centuries, cf. S. Gawlas, O kształt zjednoczonego Królestwa..., pp. 76-79. 
All attempts to move away from the consensual style of government and institutionalize direct central rule in the provinces ended in failure. On this front the hereditary Piast rulers lost the battle practically as soon as it began; meanwhile, the elective German monarchs were able to push ahead and, in the course of about one hundred years, successfully extend their power. In my opinion a key to the explanation of that striking divergence lies in the different status of the Polish dukes and the German territorial rulers. It matters a great deal if a person put in charge of a province belongs to the ruling dynasty or is an outsider from a noble family, practically and formally worse than his "rival", "born to rule". A junior duke would automatically have a higher profile; ${ }^{39}$ the duke senior could not put too much pressure on his relative without humiliating him and driving him to rebel. It is no accident, therefore, that the most appropriate illustration of Model I is the story of a minor (young Bolesław the Wrymouth in Wrocław) succeeded in the role of the head of the province by another princeps' son, Bolesław the Tall.

From the point of view of the senior dukes such an arrangement reduced to a minimum the risk of a rebellion, while for the young dukes it was the first step, in no way dishonorable, up the political ladder.

To conclude, as already during the rule of Władysław I Herman the Piast dynasty made use of three types of "employing" junior heirs to the throne in the provincial administration, we need to make a critical scrutiny of the whole subsequent history of the second Piast monarchy - at least until the first dramatic collapse of the principate - focusing on the implementation of the models of government described here, and, if necessary, identify other instruments of statecraft employed by the senior dukes. Hopefully, the application of this approach to the history of the second Piast monarchy should give us a better grasp of the complex politics and constitutional changes that transformed a uniform, top-down system of government into a conglomerate of devolved dukedoms.

Translated by Andrzej Branny

\section{Bibliography}

\section{Sources}

Galli Anonymi cronica et gesta ducum sive principum Polonorum, ed. and introd. by K. Maleczyński, "Monumenta Poloniae Historica", series II, vol. 2, Kraków 1952.

Kronika Polska (Chronica Polonorum), ed. L. Ćwikliński, "Monumenta Poloniae Historica", vol. 3, Lwów 1878, pp. 578-656.

Ksiega bracka i nekrolog opactwa Panny Marii w Lubiniu (Liber fraternitatis et liber mortuorum Abbatiae Sancte Mariae Lubinensis), ed. and introd. by Z. Perzanowski, "Monumenta Poloniae Historica", series II, vol. 9, part 2, Warszawa 1976, pp. 3-14.

Liber formularum ad ius canonicum spectantium, ex actis Jacobi de Kurdwanow episcopi Plocensis maxima parte depromptarum, ed. B. Ulanowski, Archiwum Komisji Prawniczej, vol. 1, pp. 1-35.

39 Cf. J. Bieniak, Polska elita..., part I, p. 42.

Artykuły - Articles 
Magistri Vincentii dicti Kadtubek Chronica Polonorum, ed. M. Plezia, Monumenta Poloniae Historica, Series II, Vol. 9, Kraków 1994.

Schlesisches Urkundenbuch, Vol. 1: 971-1230, eds. J.J. Menzel and H. Appelt, revised by H. Appelt, Köln-Graz 1963.

\section{Monographs}

Benyskiewicz K., Władysław Herman. Ksiązę Polski 1079-1102 [Władysław Herman: Duke of Poland, 1079-1102], Kraków 2014.

Białuński G., Wizna na pograniczu polsko-pruskim w czasach księcia Bolesława Kędzierzawego [Wizna on the Polish-Prussian border during the reign of Bolestaw IV the Curly] [in:] Pogranicze polsko-pruskie i krzyżackie. Materiaty z konferencji naukowej Górzno 1-2 czerwca 2002 r. [The Polish-Prussian and Polish-Teutonic Order borderlands: Conference proceedings, Górzno 1-2 June 2002], ed. K. Grążawski, Włocławek-Brodnica 2003, pp. 255-276.

Bieniak J., Polska elita polityczna XII wieku, Cz. 1: Tło działalności [Polish political elites of the 12 $2^{\text {th }}$ century: part I: The background] [in:] Społeczeństwo Polski średniowiecznej [Polish medieval society], vol. 2, ed. S.K. Kuczyński, Warszawa 1982, pp. 11-61.

Bieniak J., Polska elita polityczna XII wieku, cz. III A: Arbitrzy ksiażą - krag rodzinny Piotra Whostowica [Polish political elites of the $12^{\text {th }}$ century, part III A: Arbiters of princes Piotr Włostowic's family circle] [in:] Społeczeństwo Polski średniowiecznej [Polish medieval society], vol. 4, ed. S.K. Kuczyński, Warszawa 1990, pp. 13-107.

Bieniak J., Polska elita polityczna XII wieku, cz. IV B: Dwa możnowtadztwa - starszy i nowi [Polish political elites of the $12^{\text {th }}$ century, part IV B: The old and the new powerbrokers] [in:] Spoleczeństwo Polski średniowiecznej: Zbiór studiów [Polish medieval society: A collection of studies], vol. 12, ed. S. Górzyński, Warszawa 2012, pp. 11-45.

Bieniak J., Powstanie księstwa opolsko-raciborskiego jako wyraz przeksztatcania się Polski $w$ dzielnicowa poliarchie [The creation of the Duchy of Opole-Racibórz as an example of Poland's transformation into a polyarchy of regions] [in:] Sacra Silentii provincia. 800 lat dziedzicznego księstwa opolskiego (1202-2002) [Sacra Silentii provincia: Eight hundred years of a hereditary Duchy of Opole (1202-2002)], ed. A. Pobóg-Lenartowicz, Opole 2003, pp. 37-81.

Biniaś-Szkopek M., Bolesław Kędzierzawy [Bolesław the Curly], Poznań 2014.

Cetwiński M., Kasztelanowie i kasztelanie na Ślasku w XIII i XIV wieku [Castellans and castellania in Silesia in the $13^{\text {th }}$ and $14^{\text {th }}$ centuries] [in:] Studia $z$ dziejów średniowiecza polskiego i powszechnego, "Acta Universitatis Wratislaviensis" 1989, no. 979, series: Historia, vol. 69, pp. 3-20; and reprinted in: M. Cetwiński, Śląski tygiel. Studia z dziejów polskiego średniowiecza [The Silesian melting-pot: Studies in Poland's Middle Ages], Częstochowa 2001, pp. 255-275.

Dalewski Z., Modele władzy dynastycznej w Europie Środkowo-Wschodniej we wcześniejszym średniowieczu [Models of dynastic government in Central and Eastern Europe in the Early [High] Middle Ages], Warszawa 2014.

Dąbrowski F., Studia nad administracją kasztelańska Polski XIII wieku [Studies of Poland's castellan administration in the $13^{\text {th }}$ century],Warszawa 2007.

Dowiat J., Polska - państwem średniowiecznej Europy [Poland: A state of medieval Europe], Warszawa 1968.

Eberl I., Pfalzgraf [in:] Lexikon des Mittelalters, vol. 6, columns 2011-2013.

Fokt K., Denuo de Legenicensi potestate: uwagi o znaczeniu Legnicy w księstwie Bolesława Wysokiego [Denuo de Legenicensi potestate: Some remarks about the importance of Leg- 
nica in Duchy of Silesia under Bolesław I the Tall], "Śląski Kwartalnik Historyczny Sobótka” 2015, vol. 70, issue 2, pp. 3-15.

Font M., Im Spannungsfeld der christlichen Großmächte. Mittel- und Osteuropa im 10.-12. Jahrhundert, Herne 2008.

Gawlas S., O ksztalt zjednoczonego Królestwa. Niemieckie władztwo terytorialne a geneza społeczno-ustrojowej odrębności Polski [United Kingdom - what form? German territorial rule and the origin of Poland's social and constitutional identity], $2^{\text {nd }}$ ed., Warszawa 2000 ( $1^{\text {st }}$ ed., Warszawa 1996).

Grodecki R., Zbigniew ksiażę Polski [Zbigniew, Duke of Poland] [in:] Studja staropolskie. Ksiega ku czci Aleksandra Brücknera [Studies of Old Poland: A Festchrift in Honour of Aleksander Brückner], Kraków 1928, pp. 71-105.

Jurek T., Review of Jacek Osiński Statut Bolesława Krzywoustego, Wydawnictwo Avalon, Kraków 2014, "Roczniki Historyczne" 2015, vol. 81, pp. 230-233.

Helbig H., Der Wettinische Ständestaat: Untersuchungen zur Geschichte des Ständewesens und der landständischen Verfassung in Mitteldeutschland bis 1485, "Mitteldeutsche Forschungen”, vol. 4, Münster-Köln 1955.

Kosonowski M., Dokumenty księżnej Salomei i księcia Mieszka Starego dla klasztoru Benedyktynów w Mogilnie z XVII-wiecznego kopiariusza Archiwum Krakowskiej Kapituły Katedralnej. Studium krytyczne i edycja tekstów [Documents of Duchess Salomea and Duke Mieszko the Old [addressed to] the Benedictine Abbey at Mogilno [as copied] in a 17th-century cartulary of the Cracow Chapter Archives: A critical study and critical edition of the texts] [in:] Signa. Studia i szkice z nauk pomocniczych historii. Prace dedykowane Profesorowi Zenonowi Piechowi $w$ sześćdziesiata rocznice urodzin [Signa. Studies and essays in auxiliary sciences of history: A Festschrift in Honour of Professor Zenon Piech on his $60^{\text {th }}$ birthday anniversary], eds. A. Marzec, M. Starzyński, "Studenckie Zeszyty Historyczne Koła Naukowego Historyków Studentów UJ”, no. 21, Appendix 1, pp. 29-58, Kraków 2014.

Kosonowski M., O ustawie sukcesyjnej Bolesława Krzywoustego w kontrowersyjnym oświetleniu. W zwiazku z praca Jacka Osińskiego Statut Bolesława Krzywoustego, Wydawnictwo Avalon, Kraków 2014 [Bolestaw the Wrymouth's Statute of Succession: A polemic prompted by Jacek Osiński's study Statut Bolesława Krzywoustego, Avalon Publishing House, Kraków 2014], CPH 2015, vol. 67, issue 2, pp. 237-269.

Kotljar M.F, Rička V.M./Котляр М. Ф., Ричка В. М., Княжий двір Південної Русі $X-X I I I$ ст. [Princely court of Southern Rus' in the $10^{\text {th }}-12^{\text {th }}$ centuries], Kyiv 2008.

Krawiec A., Król bez korony. Władysław I Herman, ksiąze polski [King without a Crown: Władystaw I Herman, Duke of Poland], Warszawa 2014.

Labuda G., Władysław i Zbigniew. U genezy podziałów dzielnicowych w Polsce w drugiej połowie XI wieku [Władystaw and Zbigniew: The root causes of Poland's fragmentation in the later $11^{\text {th }}$ century] [in:] Spoleczeństwo Polski średniowiecznej [Polish medieval society], vol. 6, ed. S.K. Kuczyński, Warszawa 1994, pp. 9-21.

Lalik T., Sandomierskie we wcześniejszym średniowieczu. Prowincja, księstwo, województwo [Land Sandomierz in the Early Middle Ages: Province, duchy, voivodship] [in:] Studia sandomierskie. Materiały do dziejów miasta Sandomierza i regionu sandomierskiego [Studies on Sandomierz. Material to the history of the city of Sandomierz and its region], ed. T. Wąsowicz, J. Pazdur, Warszawa 1967, pp. 41-109.

Łowmiański H., Początki Polski. Polityczne i spoleczne procesy ksztaltowania się narodu do poczatku wieku XIV [The emergence of Poland: Political and social aspects of the nationbuilding processes until the $14^{\text {th }}$ century], part 1, Warszawa 1985.

Łowmiański H., Rozdrobnienie feudalne Polski w historiografii naukowej [Poland's feudal fragmentation in academic historiography] [in:] Polska w okresie rozdrobnienia feudalnego [Poland in the Age of Feudal Fragmentation], ed. H. Łowmiański, Wrocław 1973, pp. 7-34.

Artykuły - Articles 
Maleczyński K., Bolesław Krzywousty. Zarys panowania [Bolestaw the Wrymouth: An outline history of his reign], Kraków 1947.

Maleczyński K., Śląsk w okresie od schyłku IX do połowy XII wieku [Silesia from the turn of the $9^{\text {th }}$ century until the middle of the $12^{\text {th }}$ centuries] [in:] Historia Slaska [History of Silesia], vol. 1: Do roku 1763 [Prior to 1763], part 1: Do połowy XIV w. [Prior to the mid-14 ${ }^{\text {th }}$ century], ed. K. Maleczyński Wrocław 1960, pp. 145-237.

Modzelewski K., Chtopi $w$ monarchii wczesnopiastowskiej [Peasants in the early Piast monarchy], vol. 1 of Chłopi $w$ społeczeństwie polskim [Peasants in Polish society], ed. Cz. Madajczyk, Wrocław 1987.

Modzelewski K., Organizacja gospodarcza państwa piastowskiego: X-XIII wiek [The economic system of the Piast state in the $10^{\text {th }}-13^{\text {th }}$ centuries], $2^{\text {nd }}$ ed., Poznan $2000\left(1^{\text {st }}\right.$ ed., Wrocław 1975).

Mosingiewicz K., Śliwiński B., Rycerstwo polskie z końca XII w. w falsyfikacie Kazimierza Sprawiedliwego [Polish knighthood of the late $12^{\text {th }}$ century in the forged document of Kazimierz the Just], "Kwartalnik Historyczny" 1981, vol. 88, issue 3, pp. 713-722.

Paulus Ch., Das Pfalzgrafenamt in Bayern im frühen und hohen Mittelalter, Kommission für bayerische Landesgeschichte: Studien zur bayerischen Verfassungs- und Sozialgeschichte, Arbeiten aus der historischen Atlasforschung in Bayern, vol. 25, München 2007.

Schlesinger W., Zur Gerichtsverfassung des Markengebiets östlich der Saale im Zeitalter der deutschen Ostsiedlung, "Jahrbuch für die Geschichte Mittel- und Ostdeutschlands" 1953, no. 2, pp. 1-93.

Schlick J., König, Fürsten und Reich (1056-1159): Herrschaftsverständnis im Wandel, "Mittelalter-Forschungen", vol. 7, Stuttgart 2001.

Schneidmüller B., Konsensuale Herrschaft. Ein Essay über Formen und Konzepte politischer Ordnung im Mittelalter [in:] Reich, Regionen und Europa in Mittelalter und Neuzeit. Festschrift für Peter Moraw, ed. P.-J. Heinig, Berlin 2000, pp. 53-87.

Spors J., Podziat dzielnicowy Polski wedtug statutu Bolesława Krzywoustego ze szczególnym uwzglednieniem dzielnicy seniorackiej [Poland's devolution in Bolesław the Wrymouth's Statute of Succession and the seniorate province], Stupsk 1978.

Spors J., Uwagi nad geneza urzędu wojewody dzielnicowego w Polsce XII-poczatku XIII wieku [Origins of the office of the provincial voivode in Poland (12 $2^{\text {th }}$ early $13^{\text {th }}$ centuries)], "Przegląd Historyczny" 1991, vol. 82, issue 2, pp. 185-208.

Spors J., Wojewodowie Polski dzielnicowej w XII i XIII wieku: Przegląd wojewodów w kontekście ewolucji urzędu od godności nadwornej do urzędu ziemskiego [Voivodes of the Age of Poland's Fragmentation (12 ${ }^{\text {th }}$ and $13^{\text {th }}$ centuries): An overview of voivodes in the context of the evolution of [the meaning of] the term from a court office to a territorial governor], "Przegląd Historyczny" 1991, vol. 82, issue 3-4, pp. 353-370.

Spors J., Ze studiów nad urzędami w Polsce XI i XII w. (wojewoda, komornik, podkomorzy) [Studies on the offices in Poland in the $11^{\text {th }}-12^{\text {th }}$ centuries (voivode, camerarius, subcamerarius)], CPH 1992 (publ. 1993), vol. 44, issue 2, pp. 25-53.

Strätz H.-W., Pfalzgraf [in:] Handwörterbuch zur deutschen Rechtsgeschichte, $1^{\text {st }}$ ed., vol. 3, columns 1667-1670.

Teterycz-Puzio A., Henryk Sandomierski: Polski krzyżowiec (1126/1133 - 18 X 1166) [Henryk of Sandomierz: A Polish crusader (1126/1133 - 18 October 1166], $2^{\text {nd }}$ ed., Kraków 2015.

Thieme A., Die Burggrafschaft Altenburg: Studien zu Amt und Herrschaft im Übergang vom hohen zum späten Mittelalter, "Schriften zur Sächsischen Landesgeschichte", vol. 2, Leipzig 2001.

Urzędnicy małopolscy XII-XV wieku: Spisy [A Register of officials in Matopolska $\left(12^{\text {th }}-15^{\text {th }}\right.$ centuries)], ed. A. Gąsiorowski, J. Kurtyka et al., Wrocław 1990. 
Wasilewski T., Poland's Administrative Structure in Early Piast Times. Castra Ruled by Comites as Centres of Provinces and Territorial Administration, "Acta Poloniae Historica” 1989, vol. 44, pp. 5-31.

Wenta J., O stróżach „testamentu” Bolesława Krzywoustego [The custodians of the Bolesław the Wrymouth 's 'Testament'] [in:] Spoleczeństwo Polski średniowiecznej [Polish medieval society], vol. 8, ed. S.K. Kuczyński, Warszawa 1999, pp. 67-112.

Wiszewski P., Mieszko III Stary i jego czasy [Mieszko III the Old and his times], Wrocław 2002.

Zotz Th., Burggraf [in:] Handwörterbuch zur deutschen Rechtsgeschichte, $2^{\text {nd }}$ ed., vol. 1, columns $766-768$.

Zotz Th., Im Amt und Würden: Zur Eigenart ,offizieller “. Positionen im früheren Mittelalter, “Tel Aviver Jahrbuch für deutsche Geschichte” 1993, vol. 22, pp. 1-23.

Żerelik R., Dzieje Śląska do 1526 roku [History of Silesia prior to 1526] [in:] Historia Ślaska [History of Silesia], ed. M. Czapliński, Wrocław 2002. 